\title{
Spatio-temporal dynamics of milk production in Brazil
}

\section{Dinâmica espaço-temporal da produção de leite no Brasil}

\author{
Matheus Demambre Bacchi ${ }^{1}$; Alexandre Nunes Almeida ${ }^{2}$; Tiago Santos Telles ${ }^{3 *}$
}

\section{Highlights}

Milk production is concentrated in the state of Minas Gerais and Southern Brazil.

Brazil has 118 microregions and 1,238 municipalities specialize in milk production.

Approximately $20 \%$ of the microregions in Brazil specialize in milk production.

More than $22 \%$ of Brazilian municipalities specialize in milk production.

Technological overflow occurred among the milk-producing regions in Brazil.

\begin{abstract}
The milk production chain has relevance for the Brazilian economy, generating jobs and income. In addition, milk production, because of family-based farms, has an important social function. However, milk production is spatially heterogeneous in Brazil, especially due to the different technological patterns of production. In this context, the objective of this study was to verify the spatio-temporal distribution and dynamics of milk production in Brazil. For this purpose, milk production in Brazil in 2000 and 2016 was analyzed. The Brazilian microregions that specialize in milk production were identified using location quotient (LQ). An exploratory analysis of spatial data and Moran's I were used to measure spatial autocorrelation among regions. Finally, principal component analysis (PCA) was used to assess the grouping relationships of variables as a function of the regions that specialize in milk production. Between 2000 and 2016, there was a decrease in the number of microregions that specialize in milk production. Thus, in 2016, approximately $20 \%$ of the microregions and over $22 \%$ of Brazilian municipalities specialized in milk production. The microregions and municipalities that specialize in milk production were concentrated mainly in the states of Minas Gerais and Goiás and in the Southern region of Brazil. There was an increase in milk productivity in all regions of the country, especially in those regions where production was concentrated. The formation of high-high clusters was found in the most productive regions of the country, i.e., in the South and Southeast, where the effects of technological spillover were observed, and the formation of low-low clusters was observed in the less productive regions, i.e., in the North and Northeast. Two main components were formed. The first component aggregated variables related to milk production in volume, and the second component aggregated variables inherent

1 M.e Applied Economics, Escola Superior de Agricultura Luiz de Queiroz, Universidade de São Paulo, ESALQ/USP, Piracicaba, SP, Brazil. E-mail: matheusbacchi@yahoo.com.br

2 Prof. Dr., Department of Economics, Administration and Sociology, ESALQ/USP, Piracicaba, SP, Brazil. E-mail: alex.almeida@usp.br

${ }^{3}$ Researcher Dr., Instituto de Desenvolvimento Rural do Paraná, IAPAR-EMATER, Londrina, PR, Brazil. E-mail: telles@idr.pr.gov.br

* Author for correspondence
\end{abstract}

Received: July 08, 2021 - Approved: Oct. 20, 2021 
to productivity. It was possible to verify the recent growth in milk production and productivity in the country as well as to demonstrate the heterogeneity in production. Although there was a decrease in the number of microregions and municipalities that specialize in milk production, there was a concentration and increase in milk production and productivity in Brazil.

Key words: Spatial analysis. Milk supply chain. Concentration. Specialization. Heterogeneity.

\section{Resumo}

A cadeia produtiva do leite possui relevância para a economia brasileira, gerando empregos e renda. Além disso, a produção de leite, em razão da produção familiar, exerce importante função social. No entanto, a produção de leite é espacialmente heterogênea no país, sobretudo pelos diferentes padrões tecnológicos de produção. Nesse contexto, o objetivo deste estudo foi verificar a distribuição e a dinâmica espaçotemporal da produção de leite no Brasil. Para isso, foram utilizados, acerca da produção de leite no país nos anos de 2000 e 2016. Por meio do Quociente Locacional (QL), foram identificadas as microrregiões brasileiras especializadas na produção de leite. Foi realizada Análise Exploratória de Dados Espaciais (AEDE) e do I de Moran, para medir a autocorrelação espacial entre as regiões. Por fim, foi empregada a Análise de Componentes Principais (ACP), para verificar as relações de agrupamento das variáveis, em função das regiões especializadas na produção de leite. Foi identificada queda no número de microrregiões especializadas na produção de leite entre 2000 e 2016, Assim, em 2016, cerca de 20\% das microrregiões e pouco mais de $22 \%$ dos municípios do Brasil eram especializados na produção de leite. As microrregiões e municípios especializados na produção de leite estão concentrados, principalmente, nos estados de Minas Gerais e Goiás e na região Sul do Brasil. Houve aumento da produtividade de leite em todas as regiões do país, principalmente naquelas onde há concentração na produção. Constatou-se a formação de clusters Alto-Alto nas regiões mais produtivas do país, ou seja, a Sul e a Sudeste, onde se observa os efeitos do transbordamento tecnológico, bem como a formação de clusters baixo-baixo nas regiões menos produtivas, a Norte e a Nordeste. Foram formados dois componentes principais. O primeiro componente agregou variáveis relacionadas com a produção de leite em volume, enquanto o segundo componente relacionou variáveis inerentes a produtividade. Foi possível verificar o crescimento recente da produção e da produtividade de leite no país, bem como evidenciar a heterogeneidade na produção. Verificou-se que embora tenha ocorrido queda no número de microrregiões e municípios especializados na produção de leite, houve concentração e aumento na produção e produtividade de leite no Brasil.

Palavras-chave:Análise espacial. Cadeia produtiva doleite. Concentração. Especialização. Heterogeneidade.

\section{Introduction}

The production of bovine milk has great relevance for Brazilian agribusiness, being the third main product of Brazilian livestock and responsible for $5 \%$ of the gross value of production (GVP) of all agriculture in the country (Instituto Brasileiro de Geografia e Estatística [IBGE], 2020a,b). Bovine milk has a production chain that encompasses a series of products and services; it includes everything from cattle feed to transportation logistics for the processing or retail industry (M. C. Martins, 2004; Vilela, Resende, Leite, \& Alves, 2017). Among the agricultural inputs related to this chain are veterinary products, 
genetic improvements, feed, roughage, such as pasture, silage, hay and crop residues, seeds, milking and refrigeration, and fertilizers and pesticides used for food production (F. F. Lopes, Campos, \& Romeu, 2006).

Unlike the competitive grain market, dairy cattle farming is susceptible to diversification because it allows for both small- and large-scale production. In this scenario, there is livestock financing, in which families dependent on this activity opt for commercialization or for their own consumption, i.e., subsistence-oriented agriculture (Gazolla \& Schneider, 2013). In addition, products such as milk enable and stimulate the processing of inputs in areas surrounding a region, producing a local income effect.

Dairy production occurs heterogeneously throughout the Brazilian territory, and there are regions where it is more concentrated and technical than in others ( $\mathrm{J}$. F. Lopes et al., 2012; Telles, Bacchi, \& Shimizu, 2017). Beginning in the 1950s, milk production in Brazil transitioned from subsistence to income generating at a time when the country was undergoing industrialization and prices were regulated by the government (Moraes \& Bender, 2017). Starting in the 1990s, the state stopped regulating prices and opened the economy to international trade, but low productivity persisted. In recent decades, improvements in production techniques have been sought to diversify and increase the productivity of the sector as a whole (P. C. Martins \& Faria, 2006).

In the last years of the twentieth century, dairy farming garnered a considerable increase in interest from both producers and consumers. However, dairy farms were not distributed evenly throughout the national territory, with a greater concentration in the South and Southeast regions; significant expansion did occur in the Midwest region (Teixeira \& Hespanhol, 2014; Vilela et al., 2017).

In 2016, Brazil was the world's fourth largest producer of bovine milk, behind only the United States, India and China (Food and Agriculture Organization of the United Nations [FAO], 2020). However, the country has low productivity rates $(1,700$ liters per milked cow/year), occupying the 88th position in the world ranking for this indicator. According to the Brazilian Institute of Geography and Statistics (IBGE, 2020a), in 2016, of a total of 5,570 municipalities, $98.8 \%$ produced some amount of milk. In total, 33.6 billion liters of milk was produced, of which more than $70 \%$ of production was concentrated in the South (37\%) and Southeast (34\%) regions, with the remaining production distributed in the Midwest (12\%), Northeast (11\%), and North (6\%) regions.

Several changes have occurred in the milk production chain that have caused adaptations in the institutional environment that directly affect the commercial, structural and organizational spheres of the sector, even if in a varied way among regions (L. F. T. Oliveira \& Silva, 2012). Among the factors that most contributed to the increase in milk production per cow in recent years are mechanized milking, artificial insemination and embryo transfer (Maia, Pinto, Marques, Roitman, \& Lyra, 2013).

Given these facts, the characterization and mapping of dairy farming are important tools for agricultural planning by the sector given its dynamics and complexity. Because of the significant heterogeneity of dairy farming 
in terms of spatial and existing production systems, there is a need to continuously update information, especially regarding production dynamics. Such updates are also relevant for the design and definition of public actions aimed at regional development, such as the allocation of rural credit resources (Telles et al., 2017).

Some studies have been conducted to verify the spatial distribution of the main Brazilian macroregions or microregions that specialize in milk production; such studies have been conducted for the states of Minas Gerais (Lemos Galinari, Campos, Biasi, \& Santos, 2003; Perobelli, Araújo, \& Castro, 2018), Rio Grande do Sul (Marion, Fagundes, \& Schumacher, 2011), Santa Catarina (Fischer, Santos, Sehnem, \& Bernardi, 2011), and Paraná (Capucho \& Parré, 2012; Lange et al., 2016; L. H. A. Silva, Camara, \& Telles, 2016; Bánkuti, Caldas, Bánkuti, \& Granco, 2017; Telles et al., 2017) and for the South region (Telles, Bacchi, Costa, \& Schuntzemberger, 2020). In addition, although there are studies that have focused on characterizing the dynamics of specialization and on spatial distribution, these studies, for the most part, aim to analyze a specific large region or federation unit. However, more comprehensive studies on the dairy sector at the national level are still scarce. Thus, the identification and characterization of Brazilian milk-producing regions is relevant, as is an analysis of dairy activity concentration, location and specialization, to verify the heterogeneity that exists among the various regions of the country.

The proposed study is based on the hypothesis that there is uneven growth in milk production and productivity throughout the country. In addition, we hypothesize that although production is concentrated in some microregions, due to the large production in municipalities with a historical tradition of production, there is a spillover effect of production in terms of quantity produced. This spillover effects occurs mainly through technological diffusion among producers, from regions with higher production to regions with lower production. In addition, this effect has strengthened, in a more evident way, traditional dairy regions distributed throughout the national territory, especially in the South and Southeast regions. Nevertheless, there are other regions that were historically significant in the past, such as the Brazilian Cerrado, with strong participation by the state of Goiás, and other regions whose activity has relevance, such as the North and Northeast regions, which currently produce milk for specific markets.

In this context, the objective of this study was to verify the spatio-temporal distribution and dynamics of milk production in the microregions and municipalities of Brazil between 2000 and 2016. Thus, this study seeks to contribute to the existing literature on the subject by characterizing the spatial distribution of milk production throughout Brazil.

\section{Material and Methods}

Data

Data were collected for all Brazilian microregions and municipalities. Territorial cutoffs by microregion are the most used in studies involving the spatial analysis of milk production, as in Marion et al. (2011), Telles et al. (2017, 2020). However, the analysis by municipalities is also relevant for two reasons: (i) the large territorial extension of 
municipalities, especially those in the Midwest and North regions, and (ii) the importance that dairy farming has in the diffusion of technology and knowledge among producers (spillover), considering that, in general, dairy farming occurs predominantly on properties with smaller territorial extension.

Data were obtained from the Municipal Livestock Research - PPM of the Brazilian Institute of Geography and Statistics (IBGE, 2020a). Municipal Agricultural Production - PAM (IBGE, 2020b) was used to obtain agricultural product data. From these databases, the variables productivity (production in liters divided by the number of milked cows) and GVP in Brazilian Real (R\$) were obtained for the years 2000 and 2016. The year 2000 was chosen as the starting point of the analysis due to the availability of a larger number of demographic variables. In turn, 2016 was chosen due to the availability of data from both the PAM and PPM with regard to variables related to agricultural and livestock production. Thus, the time frame was chosen because space and time variation trends can be more assertively verified with the available data.

Data on the distribution of rural credits to municipalities in 2016 were obtained from the Central Bank of Brazil (BCB). Data on funding and investments, exclusively for livestock (dairy and beef), were obtained from the National Program for Strengthening Family Agriculture (PRONAF). In addition, data on livestock funding and investment modalities were obtained from the National Support Program for the Medium Rural Producer
(PRONAMP), and data were obtained from the IncentiveProgramfor Technological Innovation in Agricultural Production (INOVAGRO).

Similar to the data used by Capucho and Parré (2012), in the spatial modeling as well as in the principal component analysis (PCA), data were obtained for municipalities, such as the municipal gross domestic product (GDP) for 2015, the Municipal Human Development Index (MHDI) for 2010, and the FIRJAN Municipal Development Index (IFDM) for 2018, with the base year of 2016 .

Finally, the following data were obtained from the 2017 Census of Agriculture (IBGE) for each municipality: number of establishments where milk is produced, number of people employed in agriculture, proportion of raw cow milk sold in relation to the total milk produced, and number of milk-producing establishments per stratum of area. The latter was subdivided into three strata (Kageyama, Bergamasco, \& Oliveira, 2013): between 0.1 and 10 hectares, between 10 and 100 hectares, and greater than 100 hectares. In addition, the total number of people employed in the agricultural sector over 18 years of age was considered a variable for labor.

The set of variables, as well as the descriptive statistics, are presented in Table 1. The monetary values used in this study were updated to the value of the Brazilian Real $(\mathrm{R} \$)$ in December 2016 based on the Broad National Consumer Price Index (IPCA). Data processing was performed using the software R 3.5.1 and GeoDa 1.12, and the maps were made in QGIS 2.18. 
Table 1

Descriptive statistics of the variables used in the PCA, for the year 2016

\begin{tabular}{|ccccccc}
\hline Variables & Observations & Mean & $\begin{array}{c}\text { Standard } \\
\text { Deviation }\end{array}$ & Min & Max \\
\hline GVP & 5570 & 7090 & 14379 & 0 & 408000 \\
\hline Quantity produced & 5570 & 6043.5 & 11478 & 0 & 255000 \\
\hline Milked cows & 5570 & 3532 & 5269 & 0 & 65650 \\
\hline Productivity & 5570 & 1.47 & 1.04 & 0 & 13.73 \\
\hline LQ & 5570 & 2.52 & 2.61 & 0 & 9.45 \\
\hline FIRJAN & 5570 & 0.66 & 0.12 & 0 & 0.90 \\
Density & 5570 & 15.37 & 29.6 & 0 & 326.69 \\
GDP & 5570 & 1588824 & 15986095.6 & 16918 & 962163419 \\
HDI & 5570 & 0.65 & 0.07 & 0 & 0.85 \\
PRONAF & 5570 & 2167754 & 3874909 & 0 & 64657389 \\
\hline PRONAMP and INOVAGRO & 5570 & 1750356 & 3647753 & 0 & 72895266 \\
\hline Small establishments & 5570 & 55 & 84.59 & 0 & 1074 \\
\hline Medium-sized establishments & 5570 & 131 & 172.54 & 0 & 2617 \\
\hline Large establishments & 5570 & 32 & 56.29 & 0 & 1665 \\
\hline Population employed in agriculture & 5570 & 2700 & 2939.80 & 0 & 47651 \\
\hline
\end{tabular}

Note: GVP in thousand Brazilian Real (R\$); amount produced in thousand liters; cows milked in thousand heads.

Location quotient (LQ)

The $L Q$ is a measure of relative regional specialization; the purpose of the $L Q$ is to compare certain activities from a basic aggregate (Isserman, 1977). In this study, this parameter was used to evaluate the specialization of milk production in Brazilian microregions or municipalities based on the GVP of 2000 and 2016. The indicator was obtained from the ratio between the GVP of milk and the GVP of agriculture. A result that was higher than 1 unit indicated specialization of dairy activity in the analyzed region. The regions considered specialized in milk production had LQ values $\geq 1$ (Telles et al., 2020).
Exploratory analysis of spatial data

Exploratory analyses of spatial data involve a series of tools whose objective is to describe and visualize spatial distributions and identify outliers and spatial clusters. Using such analyses, it is possible to establish the existence of spatial autocorrelation among regions and verify whether the values of a given region depend on the values of neighboring regions (Anselin, 1995).

According to Ywata and Albuquerque (2011), Moran's I statistic can be applied directly to a variable or to the residuals of the regression of the dependent variable with a set of explanatory variables. In the first case, the criterion for choosing a spatial weight matrix 
can have a certain degree of arbitrariness or a theoretical justification based on the problem studied or be based on an empirical strategy. In the second case, the chosen matrix is based on the highest Moran's I statistic for the residuals.

Moran's I statistic varies between-1 and +1. A positive spatial autocorrelation indicates that there is similarity between the values of the attribute being study - GVP and productivity in 2000 and 2016 - and the spatial location of the attribute - microregion or municipality. Thus, a positive spatial autocorrelation indicates that in general, microregions or municipalities with high GVP or productivity tend to be surrounded by neighboring microregions or municipalities with high GVP or productivity; similarly, microregions or municipalities with low GVP or productivity would be surrounded by neighboring microregions or municipalities with low GVP or productivity. In contrast, a negative spatial autocorrelation indicates dissimilarity between the values of the attribute in question and spatial location (Anselin, 1995).

A Moran scatterplot shows all clusters in an analyzed area, even those that are not statistically significant. To overcome this problem, the local Moran significance map proposed by Anselin (1995), also known as the local indicator of spatial association (LISA), can be used. To use LISA, two criteria must be met. The first criterion is that statistically significant spatial clusters must be identifiable. The second criterion is that the sum of the local indicators should be proportional to the global spatial autocorrelation indicator (Anselin, 1995).

To facilitate the visualization of local spatial autocorrelation, a Moran dispersion diagram and spatial autocorrelation map is used. In the Moran dispersion diagram, the vertical axis represents the spatial lag, the horizontal axis represents the value of the variable, and the I statistic is the slope. The first quadrant shows high observation values for a location and its neighbors (high-high); the second quadrant shows low observation values for a location and high values for its neighbors (low-high); the third quadrant shows low observation values for both a location and its neighbors (low-low); and, finally, the fourth quadrant shows high observation values for a location and low values for its neighbors (highlow).

A matrix of spatial weights $(\mathrm{W})$ is used to configure the spatial interaction between the agents (Almeida, 2012). The matrices most commonly found are related to the geography of a region under study. That is, the matrix considers regions that share a common physical boundary as the main determinant of spatial interaction.

For this study, as in Almeida, Perobelli and Ferreira (2008), the "k nearest neighbors" matrix was chosen, considering the 20 closest neighbors. According to Gallo and Ertur (2003), the choice of this matrix, instead of other available options, such as a contiguity matrix, is preferable because it avoids methodological problems inherent to the variation in the number of neighbors, an issue that is too common in studies of municipalities or microregions.

$P C A$

PCA was performed using Brazilian municipalities that specialized in milk production in 2016 by calculating the LQ, as in Telles et al. (2020). PCA was used to 
combine the original variables with similar characteristics into components, as described in previous studies by Capucho and Parré (2012), Telles et al. (2017, 2020). In PCA, a linear combination of observed variables is sought to maximize the total variance explained. If variables are highly correlated, they can be combined, forming a component that will explain a greater amount of variance in the sample. The second component will have the second highest amount of variance and will not be correlated with the first, and so on.

An important function of multivariate analysis, especially PCA, is the reduction in the size of the variables. That is, the information regarding various variables in the study are combined to generate a reduced number of components that should explain most of the total variance in the data (Aleixo, Souza, \& Ferraudo, 2007). This reduction facilitates the interpretation of the results, as the first axes provide as much information as possible about the variables of interest (Vilpoux, 2011).

In practice, PCA aims to take $p$ variables, $X_{1}, X_{2}, \ldots, X_{\mathrm{p}}$, and find combinations to produce indices $Z_{1}, Z_{2}, \ldots, Z_{p}$ that are uncorrelated in the order of their importance and that describe the variation in the data. Thus, the lack of a correlation indicates that the indices measure different dimensions in the data, whose order is such that $\operatorname{Var}\left(Z_{1}\right) \geq$ $\operatorname{Var}\left(Z_{2}\right) \geq \cdots \geq \operatorname{Var}\left(Z_{\mathrm{p}}\right)$. The $Z$ indices are the main components. Thus, if the original variables are uncorrelated, the PCA has little relevance. The best results are obtained when the original variables have a certain degree of correlation, positive or negative (Manly, 2008). Thus, the more distant a variable is from the circle, the better its representativeness, that is, the more important the variable is for interpreting the respective components.
PCA together with the $L Q$ and the exploratory analysis of spatial data, in particular, with the local Moran's I, strengthen the analytical ability to identify potential clusters and characteristics of and gaps in the production chains in a territory. Thus, in the context of understanding and mapping dairy farming, the use of multivariate statistics emerges as an important tool to identify the spatial dependence between regions from selected relevant variables.

\section{Results and Discussion}

\section{GVP and productivity}

Figure 1 shows the GVP of milk in 2000 and 2016 in the microregions of Brazil, indicating the existence of important dairy basins in the country. In 2000, the spatial distribution of production was more homogeneous, especially in the microregions of Minas Gerais, Goiás and Paraná. In 2016, there was an intensification of activity in traditionally relevant microregions, such as Minas Gerais, as well as an increase in production in microregions in the states of Goiás, Rondônia, Mato Grosso, Tocantins, Pará, Pernambuco, Sergipe, Ceará, Bahia and Espírito Santo. However, the most significant evolution, resulting in the generation of a large milk production basin, was observed throughout the western belt of the states of Rio Grande do Sul, Santa Catarina and Paraná. The GVP of milk increased in other microregions in the South region and intensified in the Ponta Grossa microregion. 
(a)
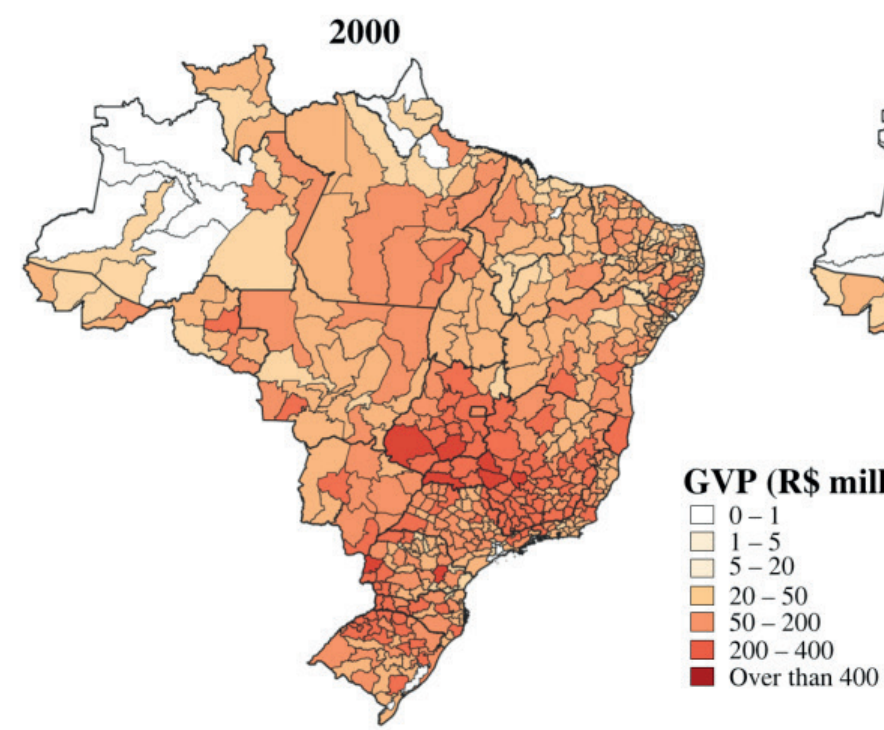

$\stackrel{N}{N} \quad \begin{array}{rrrrrr}250 & 0 & 250 & 500 & 750 & 1,000 \mathrm{~km}\end{array}$

(b)

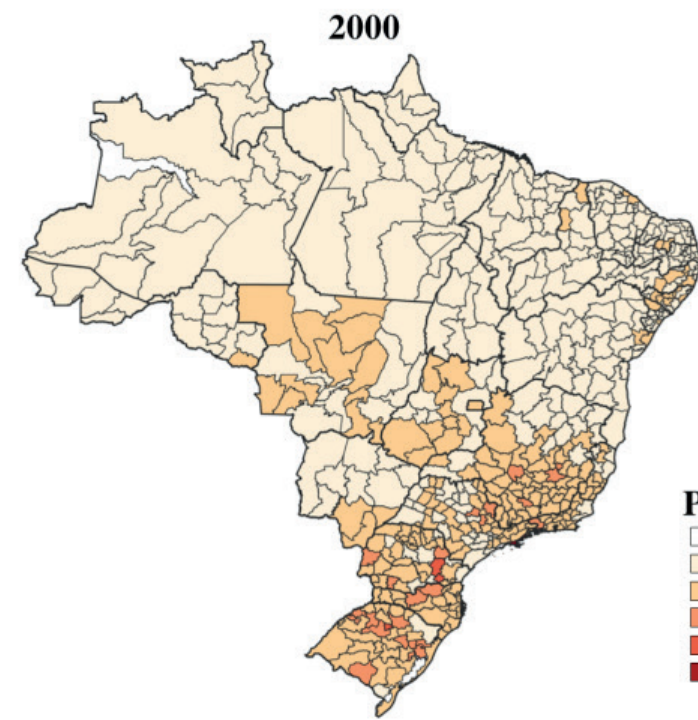

\section{Productivity}

$\square$ No production

$1-1,000$

$1,001-2,000$

$2,001-3,000$

$3,001-4,000$

Over than 4,000

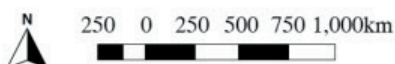

2016

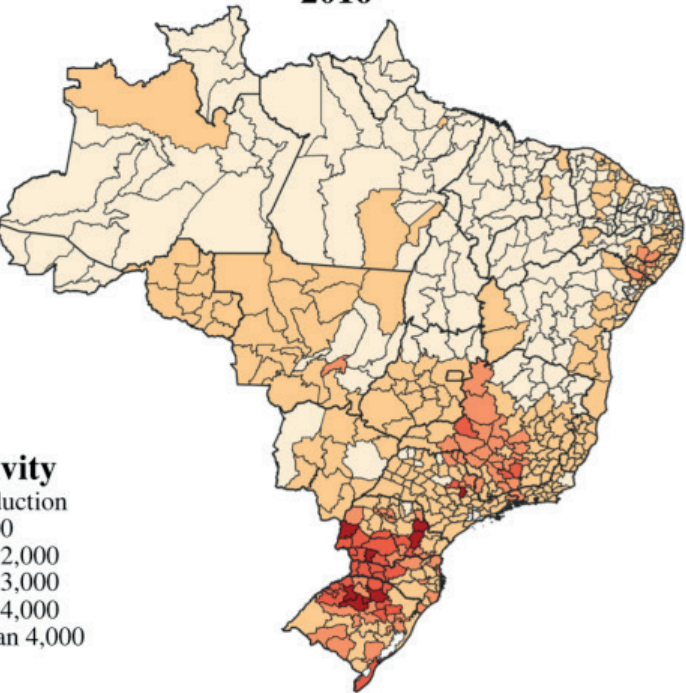

Figure 1. (a) Gross value of production (GVP) of milk in Brazilian Real (R\$), and (b) milk productivity per microregion (liters per milked cow), in 2000 and 2016.

Source: Based on data from Municipal Livestock Research (PPM) of the IBGE.

Figure $1 \mathrm{~b}$ shows the milk productivity in Brazilian microregions in 2000 and 2016; productivity growth was observed in most microregions, most notably in those located in the South and Southeast regions of the country. In terms of production, Minas Gerais was the largest milk producer in Brazil. However, the South region was identified as having the highest productivity. In addition, some microregions in the Midwestern and Northeastern regions of Brazil also stand out in terms of productivity gains. 
$L Q$

Figure 2 shows a map of Brazilian microregions and municipalities that specialize in the production of bovine milk based on the LQ for 2000 and 2016. Using the cutoff criteria of $L Q>1$ and microregions with production above the national average, there was a decrease in the number of microregions considered specialized. More specifically, based on this indicator, in 2000, of the 588 Brazilian microregions, 133 ( $22.6 \%$ of the total) specialized in the production of bovine milk, and in 2016, this number decreased by 118 ( $20 \%$ of the total), indicating a small reduction in the number of microregions that specialize in milk production in Brazil.

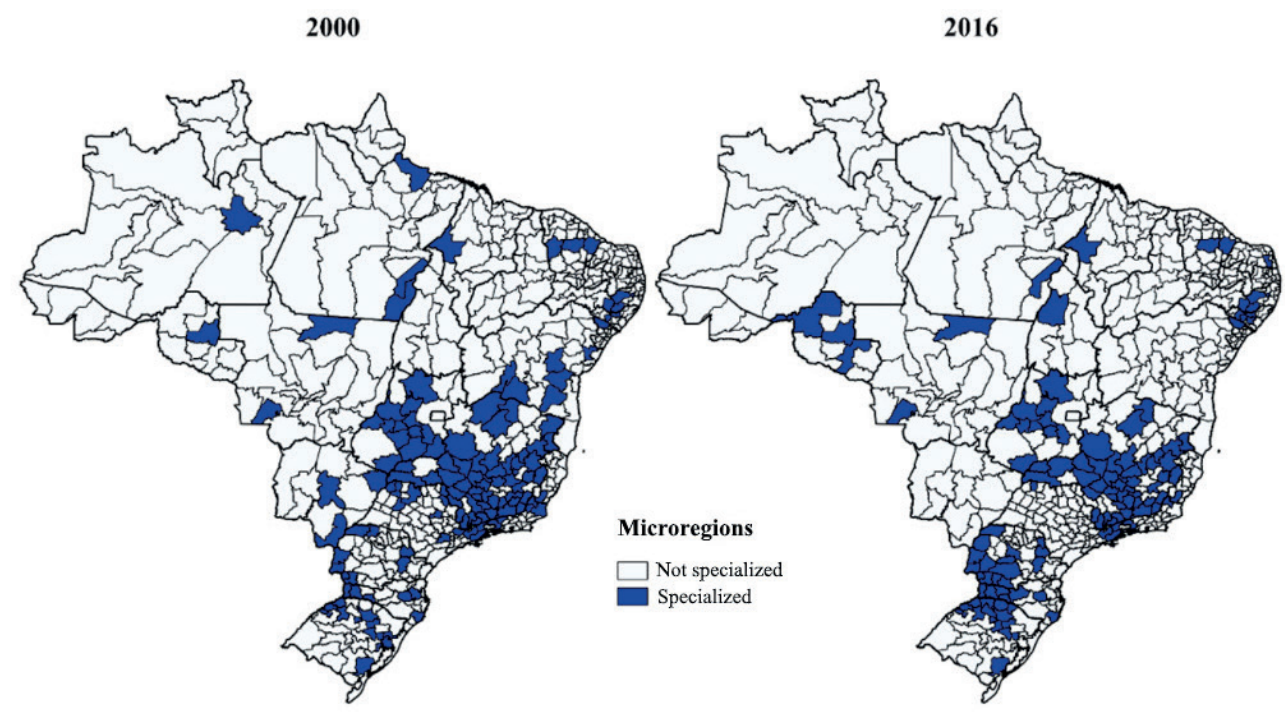

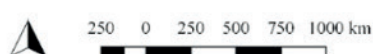

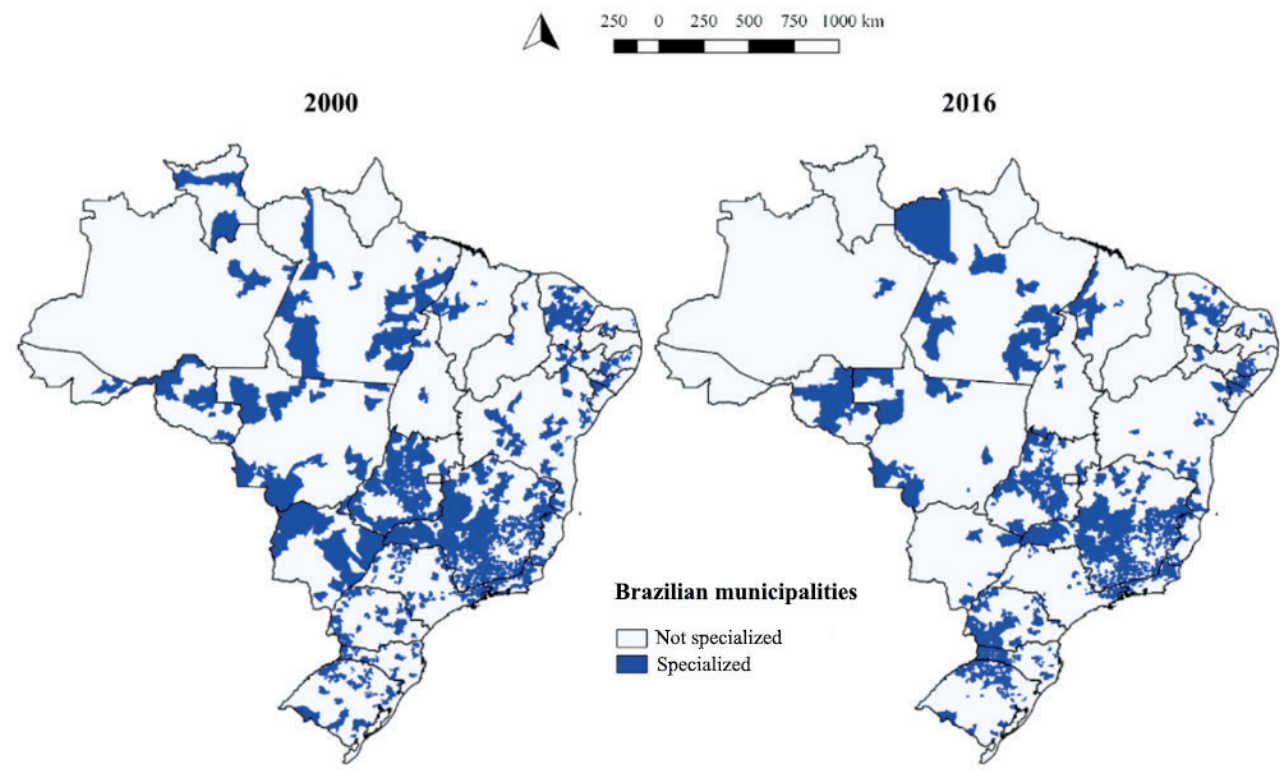

A $250 \quad 0 \quad 250 \quad 500 \quad 750 \quad 1000 \mathrm{~km}$

Figure 2. (a) Microregions and (b) Brazilian municipalities that specialized in milk production in 2000 and 2016.

Source: Based on data from Municipal Livestock Research (PPM) of the IBGE. 
As shown in Figure 2a, the largest portion of microregions that specialize in milk production were concentrated in the states of Minas Gerais and Goiás in 2000. Specifically, $47 \%$ of the microregions that specialized in milk production in that year were located in those two states. In addition, approximately $75 \%$ of the microregions in Minas Gerais were considered specialized. In addition to these states, the west region, which includes Paraná, Santa Catarina and Rio Grande do Sul, and a small portion of microregions in the Midwest, North and Northeast regions are notable.

In 2016, there was a reduction in the number of microregions considered specialized in the production of bovine milk. Additionally, as seen in Figure 2a, there was a concentration of production in some major milk-producing hubs, both commercial and family production, with a large production volume. This concentration mainly occurred in the states of Minas Gerais and Goiás but also in the South region, forming a belt throughout the central-west of the three states in the South region.

Together, the microregions in the Southern region, Minas Gerais and Goiás accounted for $78 \%$ of the total specialized microregions in 2016. Analyzing only the South region in $2000,27 \%$ of the microregions were considered specialized, increasing to $40 \%$ in 2016.

The analysis by municipality (Figure 2b) indicates that in 2000, almost all municipalities in the central-south region of Minas Gerais were specialized and bordered by specialized municipalities, i.e., Mato Grosso do Sul, São Paulo, Goiás, Rio de Janeiro, Espírito Santo and Bahia. Additionally, the number of specialized municipalities was better distributed throughout the national territory. Altogether, 1,242 municipalities were considered specialized based on the LQ. Conversely, for 2016, there was a concentration of production in the Central-South region of the country, influenced by, among other factors, the number of Southern municipalities that specialized in milk production. There was also a reduction in the number of specialized northeastern municipalities and an increase in the number of specialized municipalities in the state of Rondônia (Figure 2b). For 2016, 1,238 municipalities were considered specialized, a small decrease compared with the number for 2000.

\section{Moran's I}

The global univariate Moran's I was used to identify spatial concentrations or dispersion patterns. Figure 3 contains Moran dispersion diagrams based on milk yield per microregion for the years 2000 and 2016 as well as Moran dispersion diagrams of milk productivity by Brazilian municipality in 2000 and 2016. In the figure, the spatial lag for the variable of interest is on the vertical axis, and the value of the variable of interest is on the horizontal axis. Based on the diagrams, there is a general trend of a positive spatial association of milk productivity among the microregions. 
(a) 2000

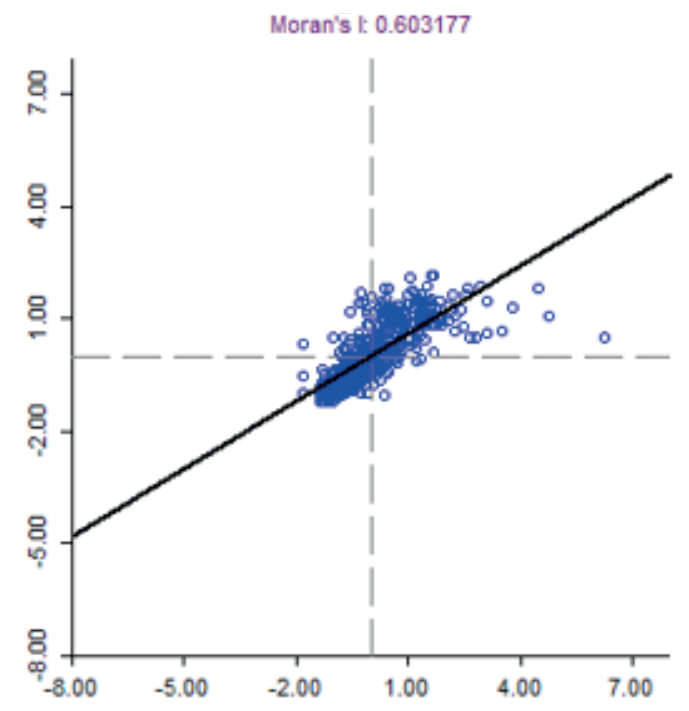

(c) 2000

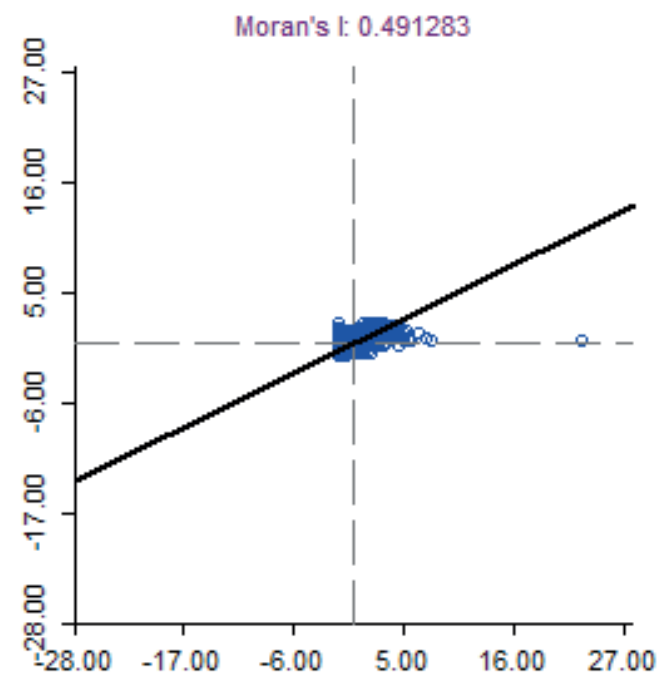

(b) 2016

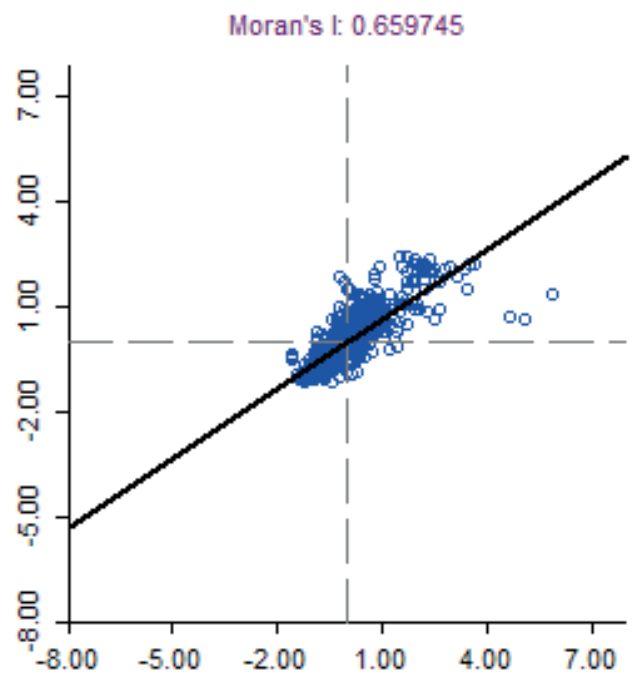

(d) 2016

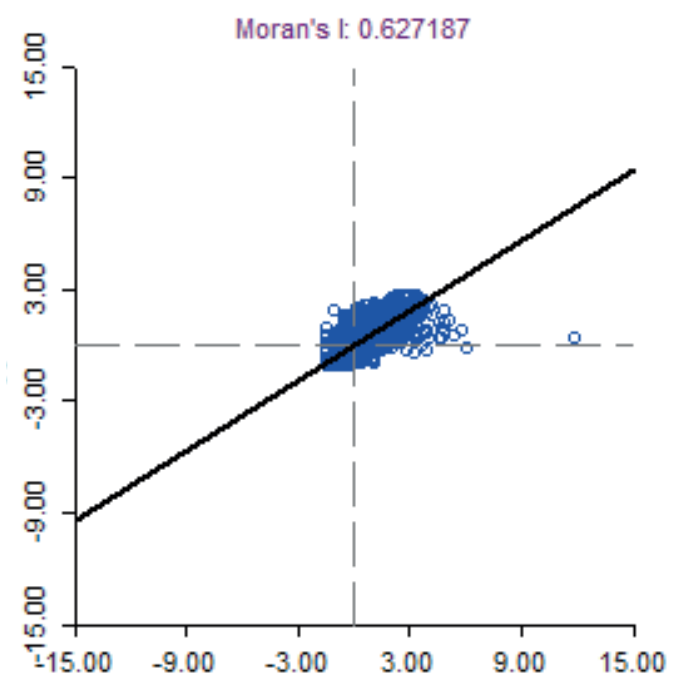

Figure 3. Moran's dispersion diagrams for milk productivity: (a) by microregion in 2000, (b) by microregion in 2016, (c) by municipality in 2000, and (d) by municipality in 2016.

For the periods analyzed, i.e., 2000 and 2016, and for the two territorial analyses, i.e., microregions and municipalities, positive angular coefficients were observed, indicating positive spatial autocorrelation in all cases. Thus, the local Moran I can be used to assess regions and their respective quadrants of interaction among their neighbors (high-high, low-low, low-high and high-low).
Regarding the local univariate Moran's I, based on the Moran dispersion diagram, the local spatial associations among microregions and their neighbors and the local spatial associations among municipalities and their neighbors for 2000 and 2016 were classified into four patterns, as shown in Figure 4. The clusters formed once again denoted the growing prominence of the South region in 
milk productivity. In 2016, as observed in Figure 4, almost all of the microregions in the states of Rio Grande do Sul, Santa Catarina and Paraná were in the high-high cluster, i.e., microregions with high productivity surrounded by neighbors with similar patterns. A similar situation occurred in the state of Minas Gerais, where despite the reduction in the number of microregions whose data were significant at 5\% between 2000 and 2016, almost all of these regions were included in the high-high cluster. The opposite occurred in the North, Northeast and part of the Midwest regions, which were classified as low-low, i.e., regions with low milk productivity surrounded by microregions also with low productivity. (a)

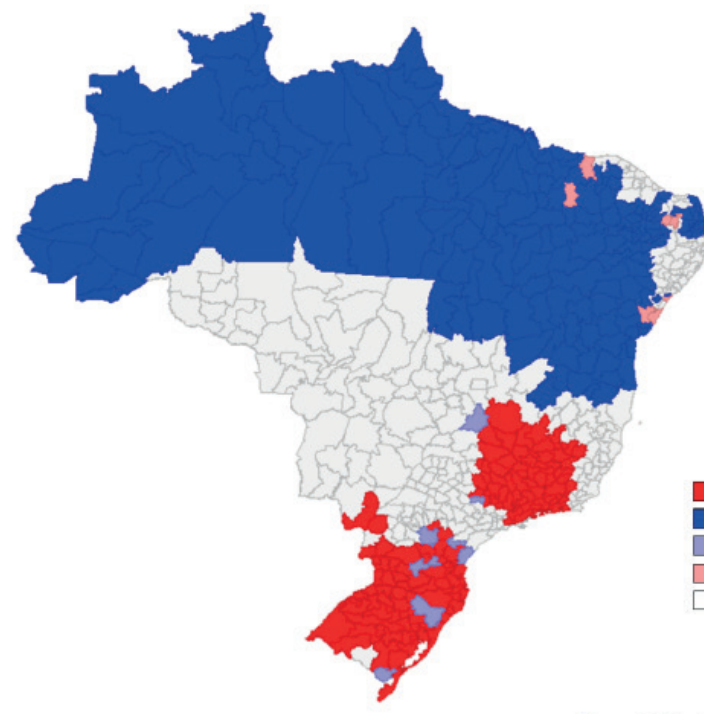

A

(c)

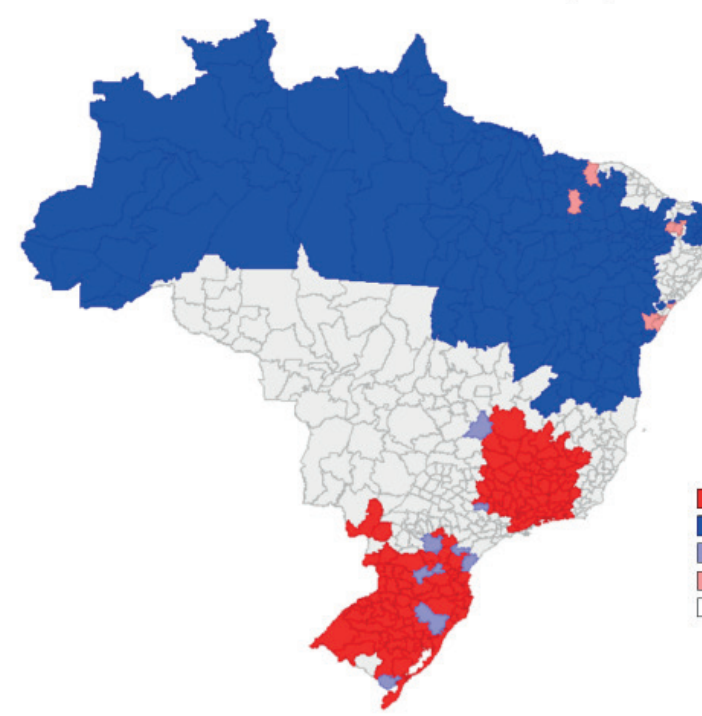

(b)

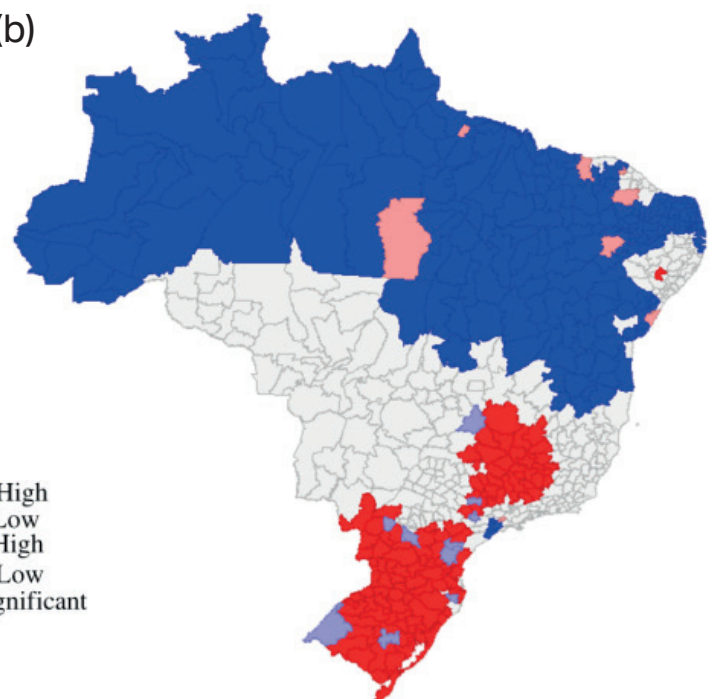

Low-Low

Low-High

High-Low

Not significan

$250 \quad 0 \quad 250 \quad 500 \quad 7501,000 \mathrm{~km}$

(d)

High-High

Low-Low

Not significan

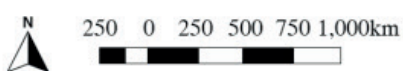

Figure 4. Milk productivity clusters in Brazil: (a) microregions in 2000, (b) microregions in 2016, (c) municipalities in 2000, and (d) municipalities in 2016. Note: $5 \%$ significance.

Source: Own elaboration. 
The analysis by municipality allowed observing, within the largest clusters formed, if municipalities with high productivity were surrounded by municipalities with similar characteristics, forming milk-producing basins. For the high-high cluster, similarity was observed, very comparable to what is shown in Figure 2, which addresses the level of specialization in production. Two large producing basins were formed, located in the central-south of Minas Gerais and throughout the midwest, i.e., Rio Grande do Sul, Santa Catarina and Paraná. In Paraná, the formation of the high-high cluster runs until the vicinity of the municipality of Castro, the municipality with the highest productivity $(7,500$ liters per milked cow/year), four times higher than the average productivity in Brazil and similar to the productivity values for countries such as Germany $(7.7$ thousand liters per milked cow/ year) and the Netherlands (8.0 thousand liters per milked cow/year), countries that are among the top 15 highest in productivity in the world (FAO, 2020). The regions with low-low clusters, based on the LQ, comprised microregions or municipalities mostly not specialized in milk production.

Many factors favor the Southern region regarding high milk production, and this region showed above-average growth. Among the factors, the South region is characterized by smaller properties. Thus, dairy cattle farming is an activity that allows for a scale in production in small areas (Parré, Bánkuti, \& Zanmaria, 2011).

Since the first half of the twentieth century, most of the agroindustries in Southern Brazil have been established in locations with a strong presence of family farming, for example, southwestern Paraná, western Santa
Catarina and northwestern Rio Grande do Sul (Picoli et al., 2015). This region accounts for the largest portion of production in the South of the country, as found by Marion et al. (2011) for Rio Grande do Sul, Fischer et al. (2011) for Santa Catarina, Telles et al. (2017) for Paraná and Telles et al. (2020) for the South region.

In addition, the South region has fertile soils, a temperate climate and water availability, contributing to high productivity, and in most cases, small farms predominate (average of 26 hectares with eight lactating cows), most with family labor, access to rural credit and even a scarcity of more profitable alternatives for producers (Picoli et al., 2015).

In the state of Paraná, particularly in the Ponta Grossa microregion, where the municipality of Castro is located, production is favored, according to Telles et al. (2017), because of the synergy of factors such as skilled labor in dairy farming, favorable edaphoclimatic conditions, a predominance of European breeds, nutritional management compatible with herd requirements and a cooperative production structure. In addition, farmers have been offered incentives for investing in agricultural research and development, and cooperatives have played a strong role in the dissemination of technology.

Thus, when analyzing the dynamics of milk production in Paraná, the results indicated increased production, a fact that has been occurring, according to Bánkuti et al. (2017), since the 1990s with a shift in production toward the South of the state. Nevertheless, according to the authors, dairy farming began to occupy areas considered "agricultural voids", establishing a new corridor for milk production in Paraná. In the Southwest of the state, production was modernized, and 
technology was expanded, with the goal of meeting the standards set by companies and cooperatives within the dairy sector in the region (Schmitz \& Santos, 2013).

In Rio Grande do Sul, the presence of a larger population favored deconcentrated production dynamics for municipalities; there was a predominance of grain production and family agriculture. Thus, the main milkproducing regions in the state were colonial regions, where family farming predominated. The development of dairy farming in the state of Rio Grande do Sul was strongly favored by the role of soybean production. In colonies inhabited by European immigrants, there may have been an accumulation of capital by producers, providing greater investments in cattle farming. These relatively capitalized producers began to face social challenges resulting from grain production due to the small size of their establishments (B. Silva \& Basso, 2005).

The rural population in Rio Grande do Sul is aging, leading to difficulties in family succession due to an instability in prices paid to producers and competitiveness with other MERCOSUR producers. A greater organization of production through cooperatives enabled better processing of milk, higher product quality, and access to financing, in addition to the possibility of crop integration (Breitenbach \& Rosolen, 2020).

In relation to Minas Gerais, the productivity differentials are related both to edaphoclimatic factors, which historically favored the development of milk production in the state, and to the adoption of technologies, mainly related to the use of artificial insemination and mechanical milking, which modernized production by rural establishments (Perobelli et al., 2018; Campos, Pereira, \& Teixeira, 2014).

In other regions of Brazil, although productivity is still low, the Cerrado region, for example, accounts for approximately $28 \%$ of the national milk production. Although most of this production in the Cerrado occurs in western Minas Gerais, other regions have gained prominence since the adoption of mapping techniques for milk production and productivity (Vilela, Andrade, \& Leite, 2018).

PCA

Figure 5 shows the relationship among the variables used in the model with two principal components. The two principal components explained $50.2 \%$ of the data variability. The first component explained $29.3 \%$, while the second explained $20.9 \%$. Note the high correlation between GVP and the quantity produced. In addition, there was a high correlation between the number of people employed in agriculture and the number of medium-sized establishments; most of this labor was allocated to properties with an area between 10 and 100 hectares. There was also a high positive correlation between the productivity variable (liters per milked cow) and the production density variable (liters per $\mathrm{km}^{2}$ ). 


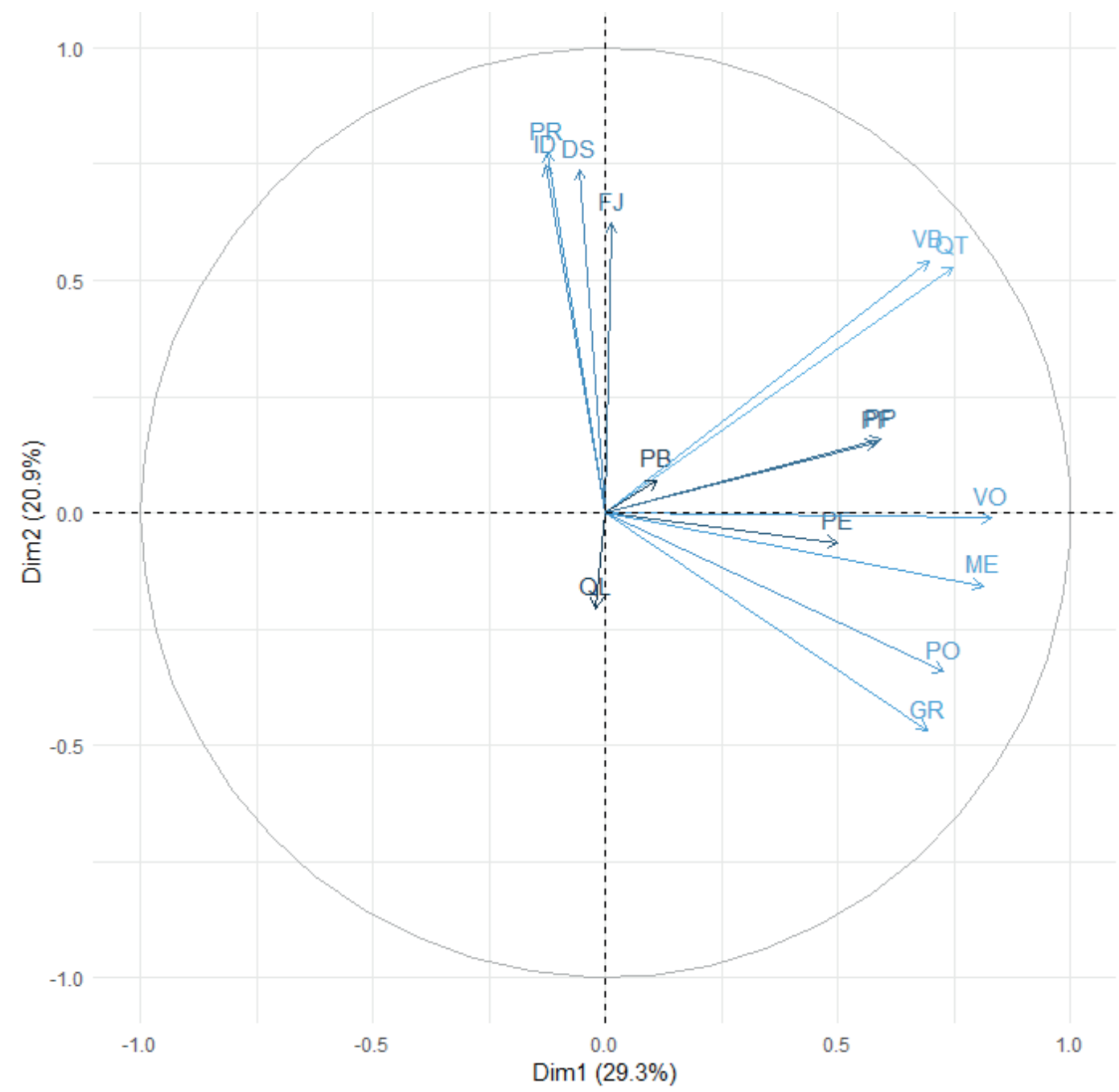

Figure 5. Relationship among PCA variables and the two principal components

Notes: Legend: VB: gross value of production; QT: amount produced; VO: milked cows; PR: productivity; QL: locational quotient; FJ: FIRJAN; SD: production density; CP: GDP; ID: HDI; PF: PRONAF; PP: PRONAMP and INOVAGRO; PE: number of small establishments; BD: number of medium-sized establishments; GR: number of large establishments; OP: population employed in agriculture.

Among the major negative correlations, the correlation between the productivity variables and the number of large establishments is noteworthy. This negative correlation can be explained by the largest establishments not having the highest milk yields and by dairy farming being a secondary activity in the largest area stratum.
The municipality of Castro, in the state of Paraná, was identified as an outlier for both production and productivity. The municipality of Patos de Minas in the state of Minas Gerais had high production but lower productivity than Castro. The municipality of Toledo, in the state of Paraná, also had high production and productivity. Another outlier was the 
municipality of Araras, in the state of São Paulo, which did not have high production as a whole but by a single farm. There were several municipalities in the North and Northeast regions whose productivity was low, but in many places, production was high, for example, Marabá, in the state of Pará, which is characterized by large production on farms of 10 to 100 hectares, with more family-based characteristics and a high use of rural credit.

It was not possible to accurately identify the effective characteristics of each component. However, the first component was correlated with those variables related to absolute milk production. The second component was correlated with those variables inherent to productivity.

Based on the LQ, Moran's I and PCA results, the South region played a substantial role in milk production and productivity in Brazil. The technological changes observed in this region have allowed significant productivity gains, especially due to genetic improvements in dairy cows and mechanical milking. Although technological changes is an indicator that reflects the efficiency and development of the sector in a given region, it does not reflect the reality of a country of the territorial magnitude of Brazil, which shows substantial heterogeneity in production characteristics in each region as well as in production volume and productivity.

The scenario in the Southeast was also positive; however, Minas Gerais, the largest milk-producing state, experienced stagnation, which did not occur in the South region. The stagnation in milk production in Minas Gerais was due to a variety of factors, including differences in regional productivity among the municipalities of Minas Gerais that, according to Perobelli et al. (2018), are due both to differences in edaphoclimatic conditions and in technological standards for production systems. Thus, the production scale and modernization of production systems are possible factors that explain the challenges in generating productivity gains and increased milk production in Minas Gerais.

In the North and Midwest regions, there were also changes in the scenario. Production facilities distant from consumer centers (as a result of advances in storage technologies) and the continuous increase in the income and consumption of the Brazilian population caused the production and collection of milk in these regions to increase, albeit in a subtle way.

In the Northeast region, despite the growth in dairy farming in recent years, milk productivity is low because, according to Ferreira, Silva, Bispo and Azevedo (2009), edaphoclimatic limitations and herd-feeding characteristics, based on the use of cultivated forage and the use of native vegetation (predominantly from the Caatinga), lead to seasonality in production. In addition, the continued growth of northeastern dairy farming, in the face of barriers linked to socioeconomic factors, is uncertain because dairy farming in the region is characterized by family subsistence production, i.e., there is a high number of producers with low productivity (subsistence system) using few technological resources, linked to management practices and milk quality, and small-scale commercialization (M. C. Oliveira, Campos, Oliveira, Ferreira, \& Melo, 2016). However, despite the restrictions, there is potential for milk production in the Northeast, such as the high demand for animal products, especially in large population centers. Therefore, there is 
room for increased production and improved productivity, especially through the adoption of technologies.

With regard to investments in new available technologies, especially in regions with low productivity, the widespread adoption of technology would certainly result in a higher level of production; additionally, it would tend to reduce the final prices paid to the producer, especially if the technology is not used for processing purposes but only for increasing productivity. However, even in this context, there would also be a reduction in production costs, which would make the activity profitable with possible gains in scale (Simões, Nicholson, Novakovic, \& Protil, 2019).

Thus, given the potential for expanding milk production in the Northeast, it is essential that the focus be on reducing costs and maximizing profits for dairy cattle farming to be sustainable. In addition, rural credits should be applied to investments in technology, the acquisition of herds with adequate genetics, the search for product quality, better pasture management and intelligent management. The government should provide subsidies in the form of credits for funding and investments and reduce taxes, with the goal of driving commercialization. In this context, milk quality is one of the most important factors for increasing demand, and Brazilian milk has improved in recent years (Vilela et al., 2017). In addition, the expansion of milk production indicates that productivity has been increasing and activity has become more specialized.

Notably, dairy cattle farming in Brazil, in general, falls far short of its potential. The presence of the country among the four largest milk producers in the world is largely due to its territorial extension, which causes a misinterpretation, incorrectly indicating a favorable scenario. The negative trade balance and low average productivity have opened up structural and logistical problems that hinder the country and prevent it from being among the most productive. Thus, to leverage the sector, there must be a favorable institutional environment that encourages the adoption of new technologies and innovations, which contribute to gains in productivity and milk quality. For this, there is a need to intensify dairy cattle farming, with an emphasis on the quantity and quality of animals through investments in personnel and machinery, in the search for more environmentally sustainable practices, in improvements to farm infrastructure, and in technical monitoring.

\section{Conclusions}

It was possible to verify the growth of milk production and productivity in Brazil. The South region is notable for an increase in production, with specialized and highly productive microregions and municipalities, and the strong use of technology, such as mechanized milking. Conversely, in traditional dairy farming regions, such as Minas Gerais, production continues to increase but with a lower growth rate. In states such as Rondônia, Pará, Ceará, Pernambuco and Alagoas, with a predominance of family production, there has been a slight increase in milk productivity, which can be explained by the greater use of rural credits for funding and investments.

In addition, there are regions in Brazil where it is possible to verify spillover effects from highly productive regions to regions with low productivity. These spatial dynamics have reduced heterogeneities at the microregional 
level, but over time, may generate a more competitive environment, both within large regions and throughout Brazil.

In this sense, it is important to emphasize the role of research in the development of innovations for all branches of agriculture, including milk production. Studies aimed at animal reproduction, genetic improvements, intensive pasture management and the socioeconomic aspects of milk production systems are essential for improving not only quantity but also quality.

Equally relevant is the participation of rural extension programs and technical assistance. The diffusion of technology and the monitoring of the managerial and technical capabilities of properties and their productivity gains are very important.

\section{References}

Aleixo, S. S., Souza, J. G., \& Ferraudo, A. S. (2007). Técnicas de análise multivariada na determinação de grupos homogêneos de produtores de leite. Revista Brasileira de Zootecnia, 36(6), 2168-2175. doi: 10. 1590/S1516-35982007000900029

Almeida, E. (2012). Econometria espacial aplicada. Campinas, SP: Alínea.

Almeida, E. S., Perobelli, F. S., \& Ferreira, P. G. C. (2008). Existe convergência espacial da produtividade agrícola no Brasil? Revista de Economia e Sociologia Rural, 46(1), 31-52. doi: 10.1590/S0103-200320 08000100002

Anselin, L. (1995). Local indicators of spatial association - LISA. Geographical Analysis, 27(2), 93-115. doi: 10.1111/j.1538-4632. 1995.tb00338.x
Bánkuti, F. I., Caldas, M. M., Bánkuti, S. M. S., \& Granco, G. (2017). Spatial dynamics: a new "milk corridor" in Paraná State, Brazil. Semina: Ciências Agrárias, 38(4), 2107-2118. doi: 10.5433/1679-0359.20 $17 v 38 n 4 p 2107$

Breitenbach, R., \& Rosolen, G. (2020). Análise estratégica do setor produtivo de leite do Rio Grande do Sul. Revista de Política Agrícola, 29(4), 83-97.

Campos, S. A. C., Pereira, M. W. G., \& Teixeira, E. C. (2014). Trajetória de modernização da agropecuária mineira no período de 1996 a 2006. Economia Aplicada, 18(4), 717739. doi: 10.1590/1413-8050/ea115282

Capucho, T. O., \& Parré, J. L. (2012). Produção leiteira no Paraná: um estudo considerando os efeitos espaciais. Informe GEPEC, 16(1), 112-127. doi: 10.48075/igepec.v16i1.5103

Ferreira, M. A., Silva, F. M., Bispo, S. V., \& Azevedo, M. (2009). Estratégias na suplementação de vacas leiteiras no semi-árido do Brasil. Revista Brasileira de Zootecnia, 38(Esp.), 322-329. doi: 10.1590/S151635982009001300032

Fischer, A., Santos, J. S., Sehnem, S., \& Bernardi, I. (2011). Produção e produtividade de leite no Oeste catarinense. Revista de Administração, Contabilidade e Economia, 10(2), 337-362.

Food and Agriculture Organization of the United Nations (2020). FAOSTAT. Retrieved from http://www. fao.org

Gallo, J. L., \& Ertur, C. (2003). Exploratory spatial data analysis of the distribution of regional per capita. GDP in Europe, 1980-1995. Papers in Regional Science, 82, 175-201. doi: $10.1007 / s 101100300145$

Gazolla, M., \& Schneider, S. (2013). Qual "fortalecimento" da agricultura familiar? Uma análise do Pronaf crédito de custeio 
e investimento no Rio Grande do Sul. Revista de Economia e Sociologia Rural, 51(1), 45-68. doi: 10.1590/S0103-20032 013000100003

Instituto Brasileiro de Geografia e Estatística (2020a). Pesquisa da pecuária municipal - PPM. Recuperado de https://sidra.ibge. gov.br

Instituto Brasileiro de Geografia e Estatística (2020b). Produção agrícola municipal PAM. Recuperado de https://sidra.ibge. gov.br

Isserman, A. (1977). The Locational Quotient approach to estimating regional economic impacts. Journal of the American Institute of Planners, 43(1), 33-41. doi: 10. 1080/01944367708977758

Kageyama, A. A., Bergamasco, S. M. P. P., \& Oliveira, J. T. A. (2013). Uma tipologia dos estabelecimentos agropecuários do Brasil a partir do Censo de 2006. Revista de Economia e Sociologia Rural, 51(1), 105-122. doi: 10.1590/S0103-200 32013000100006

Lange, M. J., Zambom, M. A., Ramos, C. E. C. O., Castagnara, D. D., Bánkuti, F. I., Neumann, M. E., Tinini, R. C. R. (2016). Typology of dairy production systems based on the characteristics of management in the Region of West Paraná. Semina: Ciências Agrárias, 37(1), 473-482. doi: 10.5433/ 1679-0359.2016v37n1p47

Lemos, M. B., Galinari, R., Campos, B., Biasi, E., \& Santos, F. (2003). Tecnologia, especialização regional e produtividade: um estudo da pecuária leiteira em Minas Gerais. Revista de Economia e Sociologia Rural, 41(3), 117-138. doi: 10.1590/S010320032003000300006

Lopes, J. F., Jr., Ramos, C. E. C. O., Santos, G. T., Grande, P. A., Damasceno, J. C., \& Massuda, E. M. (2012). Análise das práticas de produtores em sistemas de produção leiteiros e seus resultados na produção e qualidade do leite. Semina: Ciências Agrárias, 33(3), 1199-1208. doi: 10.5433/1679-0359. 2012v33n3p11

Lopes, F. F., Campos, E. M., \& Romeu, J. C. (2006). Insumos agropecuários. In M. A Cônsoli, \& M. F. Neves (Coords.), Estratégias para o leite no Brasil (pp. 66-89). São Paulo, SP: Atlas.

Maia, G. B. S., Pinto, A. R., Marques, C. Y. T., Roitman, F. B., \& Lyra, D. D. (2013). Produção leiteira no Brasil. BNDES Setorial, 37, 371398.

Manly, B. (2008). Métodos estatísticos multivariados: uma introdução. Porto Alegre, RS: Bookman.

Marion, P. J., F., Fagundes, J. O., \& Schumacher, G. (2011). A produção de leite no Rio Grande do Sul: produtividade, especialização e concentração (1990-2009). Revista de Economia e Agronegócio, 9(2), 233-252. doi: 10.25070/rea.v9i2.185

Martins, M. C. (2004). Competitividade da cadeia produtiva do leite no Brasil. Revista de Política Agrícola, 13(3), 38-51.

Martins, P. C., \& Faria, V. P. (2006). Histórico do leite no Brasil. In M. A. Cônsoli, \& M. F. Neves (Coords.), Estratégias para o leite no Brasil (pp. 48-65). São Paulo, SP: Atlas.

Moraes, B. M. M., \& Bender, R., Fo. (2017). Mercado brasileiro de lácteos: análise do impacto de políticas de estímulo à produção. Revista de Economia e Sociologia Rural, 55(4), 783-800. doi: 10.1590/1234-56781806-94790550410

Oliveira, L. F. T., \& Silva, S. P. (2012). Mudanças institucionais e produção familiar na cadeia produtiva do leite no Oeste Catarinense. Revista de Economia e Sociologia Rural, 50(4), 705-720. doi: 10.1590/S0103-2003 2012000400007 
Oliveira, M. C., Campos, J. M. S., Oliveira, A. S., Ferreira, M. A., \& Melo, A. A. S. (2016). Benchmarks for milk production systems in the Pernambuco Agreste region, Northeastern Brazil. Revista Caatinga, 29(3), 725-734. doi: 10.1590/ 1983-21252016v29n324rc

Parré, J. L., Bánkuti, S. M. S., \& Zanmaria, N A. (2011). Perfil socioeconômico de produtores de leite da região sudoeste do Paraná: um estudo a partir de diferentes níveis de produtividade. Revista de Economia e Agronegócio, 9(2), 275-300. doi: 10.25070/rea.v9i2.187

Perobelli, F. S., Araújo, I. F., Jr., \& Castro, L. S. (2018). As dimensões espaciais da cadeia produtiva do leite em Minas Gerais. Nova Economia, 28(1), 297-337. doi: 10.1590/ 0103-6351/4789

Picoli, T., Zani, J. L., Peter, C. M., Roll, V. F. B., Ribeiro, M. E. R., Vargas, G. D., Fischer, G. (2015). Milk production characteristics in Southern Brazil. Semina: Ciências Agrárias, 36(Suppl. 3), 1991-1998. doi: 10.5433/1679-0359.2015v36n3Supl1 p19

Schmitz, A. M., \& Santos, R. A. (2013). A produção de leite na agricultura familiar do Sudoeste do Paraná e a participação das mulheres no processo produtivo. Terra Plural, 7(2), 339-355. doi: 10.5212/ Terra Plural.v.7i2.0010

Silva, B., Neto, \& Basso, D. (2005). A produção de leite como estratégia de desenvolvimento para o Rio Grande do Sul. Desenvolvimento em Questão, 3(5), 53-72. doi: 10.21527/2237-6453.2005.5.53-72

Silva, L. H. A., Camara, M. R. G., \& Telles, T. S. (2016). Evolução e distribuição espacial da produção de leite no estado do Paraná. Acta Scientiarum. Human and Social Sciences, 38(1), 37-47. doi: 10.4025/ actascihumansoc.v38i1.30006
Simões, A., Nicholson, C., Novakovic, A., \& Protil, R. (2019). Dynamic impacts of farmlevel technology adoption on the Brazilian dairy supply chain. International Food and Agribusiness Management Review, 23(1), 71-84. doi: 10.22434/IFAMR2019.0033

Teixeira, J. C., \& Hespanhol, A. N. (2014). A trajetória da pecuária bovina brasileira. Caderno Prudentino de Geografia, 36(2), 26-38.

Telles, T. S., Bacchi, M. D., \& Shimizu, J. (2017). Spatial distribution of microregions specialized in milk production. Semina: Ciências Agrárias, 38(1), 443-553. doi: 10.5433/1679-0359.2017v38n1p443

Telles, T. S., Bacchi, M. D., Costa, G. V., \& Schuntzemberger, A. (2020). Milk production systems in Southern Brazil. Anais da Academia Brasileira de Ciências, 92(01), e20180852. doi: 10.1590/00013765202020180852

Vilela, D., Andrade, R., \& Leite, J. L. (2018). O leite no Cerrado. $\mathrm{O}$ que esperar em ganhos de produção e produtividade. Revista de Política Agrícola, 28(2), 66-78.

Vilela, D., Resende, J. C., Leite, J. B., \& Alves, E. (2017). A evolução do leite no Brasil em cinco décadas. Revista de Política Agrícola, 26(1), 5-24.

Vilpoux, O. (2011). Desempenho dos arranjos institucionais e minimização dos custos de transação: transações entre produtores e fecularias de mandioca. Revista de Economia e Sociologia Rural, 49(2), 271-294. doi: 10.1590/S0103-20 032011000200001

Ywata, A. X. C., \& Albuquerque, P. H. M. (2011). Métodos e modelos em econometria espacial. Uma revisão. Revista Brasileira de Biometria, 29(2), 273-306. 
